\title{
Developing Cadastres to Service Complex Property Markets
}

\author{
Jude WALLACE and Ian WILLIAMSON, Australia
}

Key words: key words, theme, etc.

\section{SUMMARY}

Emerging demands on cadastral design suggest that cadastres as a functional component of land administration are being redesigned to respond to initiatives in technology, government needs and social drivers. The movements in the property market are demonstrating the need to take into account complex commodities. The surge in regulatory requirements affecting land use and building is part of the move to legalise almost all aspects of human behaviour but pose special problems for land administration. How cadastres respond to the multiplicity of regulatory interventions is an open question. This paper considers these issues in the context of building cadastral models. Four case studies are used to illustrate these issues.

Jude Wallace and Ian Williamson 


\title{
Developing Cadastres to Service Complex Property Markets
}

\author{
Jude WALLACE and Ian WILLIAMSON, Australia
}

\section{INTRODUCTION}

The experience of building national approaches to cadastres, spatial data infrastructures (SDI) and land administration systems (LAS) in Australia, a country formed by federation of individual states, is similar to the experience of the European Union in absorbing new members and in creating sufficient degrees of commonality among members to extract benefits from organisation. In some ways, the Europeans are advantaged. At least members see value in joining a larger organisation and in making it work. Australia, by contrast, needs a forward vision of sufficient power to advance national solutions in place of the state based silos (ICSM, 1999, 2002).

The Centre for Spatial Data Infrastructures and Land Administration at the University of Melbourne has a nationally funded research project for incorporating sustainable development objectives into ICT enabled land administration systems. The project was predicated on bringing into Australia a clear vision of how integrated cadastres serviced the local economies in Switzerland, Germany, Denmark and The Netherlands. Initiatives of the international community in standardisation and modelling are therefore directly relevant to other nations.

\section{CADASTRES}

\subsection{Dynamic cadastres}

Land administration is the key to acceleration of wealth out of land (Wallace and Williamson, 2004b). The administration processes enable market participants to confidently deal in land and to create additional and secondary commodities. In most countries, cadastres are the core or base layer of land information or infrastructure, though many countries successfully run land administration and land markets without them: USA, UK and Canada. Cadastres have broadened beyond the concept in Cadastre 2014: "a methodically arranged public inventory of data concerning properties based on a survey of their boundaries". Though there is scope for debate about where the cadastre finishes and the SDI begins, incorporation of land objects and "land object boundaries" remain basic starting points (Kaufman and Steudler, 1998; FIG, 1995, para 3.18). The problem however lies in the dynamism of cadastres. Cadastral data models specify key types: real estate object, person (subject) and right or restriction (Ploeger and Stoter, 2004; Lemmen et al., 2003). However, even these simple ideas raise issues for consideration given the dynamic changes to the way land is used and recorded. Thus, the problems of settling international definitions for "real estate units" are recognised by the Working Party on Land Administration. Any particular definition must confront situations in which practical land use turns title parcels into properties, and then into areas that concern business entities or corporations who undertake commercial and agricultural uses. The realpolitik of land use therefore builds parcel, property and business activity area layers. As commercial demands grow, these layers are more integrated into the fabric of business.

Jude Wallace and Ian Williamson

Developing Cadastres to Service Complex Property Markets

Joint 'FIG Commission 7' and 'COST Action G9' Workshop on Standardisation in the Cadastral Domain Bamberg, Germany, 9 and 10 December 2004 
Cadastres must either change in response or atrophy. And models developed for standardisation of approaches to cadastres must be similarly flexible.

\subsection{Flexible approaches to standardisation}

Following FIG Statement on the Cadastre (FIG, 1995), the focus was on objects of rights restrictions and responsibilities (RRRs), away from parcels associated merely with land rights. The more flexible approach absorbs local variation in cadastres built to reflect unique conditions of the countries which created them. Technology added to local distinctions. When parcel information was digitized to deliver a layer in the form of a digital cadastral data base (DCDB) in a spatial data infrastructure capable of servicing a multitude of needs for land information and land policy, country differences were even more apparent. To reverse this trend towards local systems, the emerging Cadastral Domain Model strives to build in sufficient flexibility to allow cross-border use, and to release the energy of the digital cadastral data bases (DCDB), spatial information, information communication technology (ICT), Internet availability, geo-databases, open systems GIS and web mapping facilities.

Standardisation is particularly driven by information communication technologies along with government imperatives, including the familiar trends to privatize the public sector and to introduce new methods of accountability within government agencies. Efforts to develop shared understandings of basic infrastructure are essential counterbalances of localization trends. Thus the universalisable LAS model in Diagram 1 below reflects local situations within a generic design (Enemark, Williamson and Wallace, 2004).

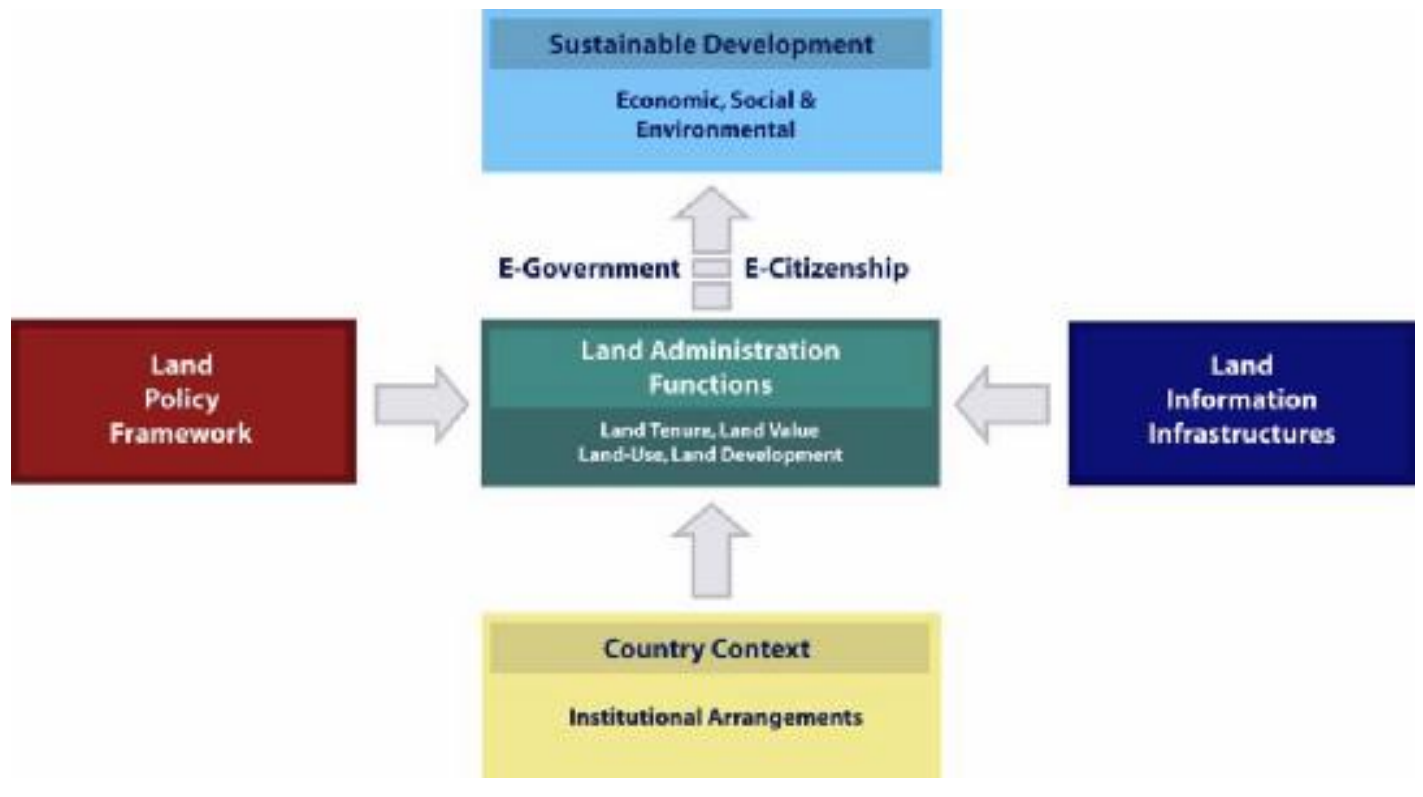

Figure 1. A model of land administration in developed economies (Enemark, Williamson and Wallace, 2004)

Jude Wallace and Ian Williamson

Developing Cadastres to Service Complex Property Markets

Joint 'FIG Commission 7' and 'COST Action G9' Workshop on Standardisation in the Cadastral Domain Bamberg, Germany, 9 and 10 December 2004 


\section{THE DYNAMIC WORLD OF PROPERTY MARKETS}

To understand how dramatically land markets have changed since land administration systems (LAS) were conceived, (Wallace and Williamson, 2004b), two other trends need to be identified. The first concerns development of high levels of sophistication in the capacity of land to support wealth creating activities. The second involves more interesting and problematic trends to commodify property derived from land but unrelated to specific parcels, or even incapable of being related to a polygon or other standard spatial definition. Land administration systems support "simple commodities" - ownership, leases and financial interests (mortgages). Simple commodities provide the foundation for rebundling of opportunities associated with direct access to land, in case of mortgages on default of the loan arrangements. Complex commodities are everything else. They raise the difficulty level to reflect much more refined opportunities of access (multi-occupancy uses), conversion of the built environment into complicated investment opportunities (time shares), abstract interests facilitating investment in land including unit and property trusts and mortgage backed certificates, and even commodities which have no relationship with land at all, which in Australia are being referred to as "new" property.

Three case studies are drawn to illustrate these emerging trends, relying on Australian experience: complex commodities, particularly mortgage backed certificates in secondary mortgage markets, "new" property, particularly water rights objects, and the plethora of restrictions and responsibilities (RRs). The case studies suggest new approaches to parcels and data sharing.

\subsection{Complex commodities}

A complete comprehensive definition is impossible because new commodities are invented constantly. These commodities cannot exist without sophisticated administrative supports, usually created by government, but not necessarily. To get the most economic energy out of these commodities, a jurisdiction must develop four capacities: abstract conceptualisation (cognitive capacity), administrative rationalisation, corporatisation, and securitisation (Wallace and Williamson, 2004b). Because design of government LAS predates much of the development of these wealth acceleration activities, and because the LAS designs are embedded in legislation and government organisation, public-run LAS are slow to adapt. Much of the administrative structure creating certainties and regularities in these commodities therefore exists in the private sector; for some commodities the infrastructure is entirely provided by the private sector. Developments in complex property markets are illustrated by Figure 2 .

Jude Wallace and Ian Williamson 


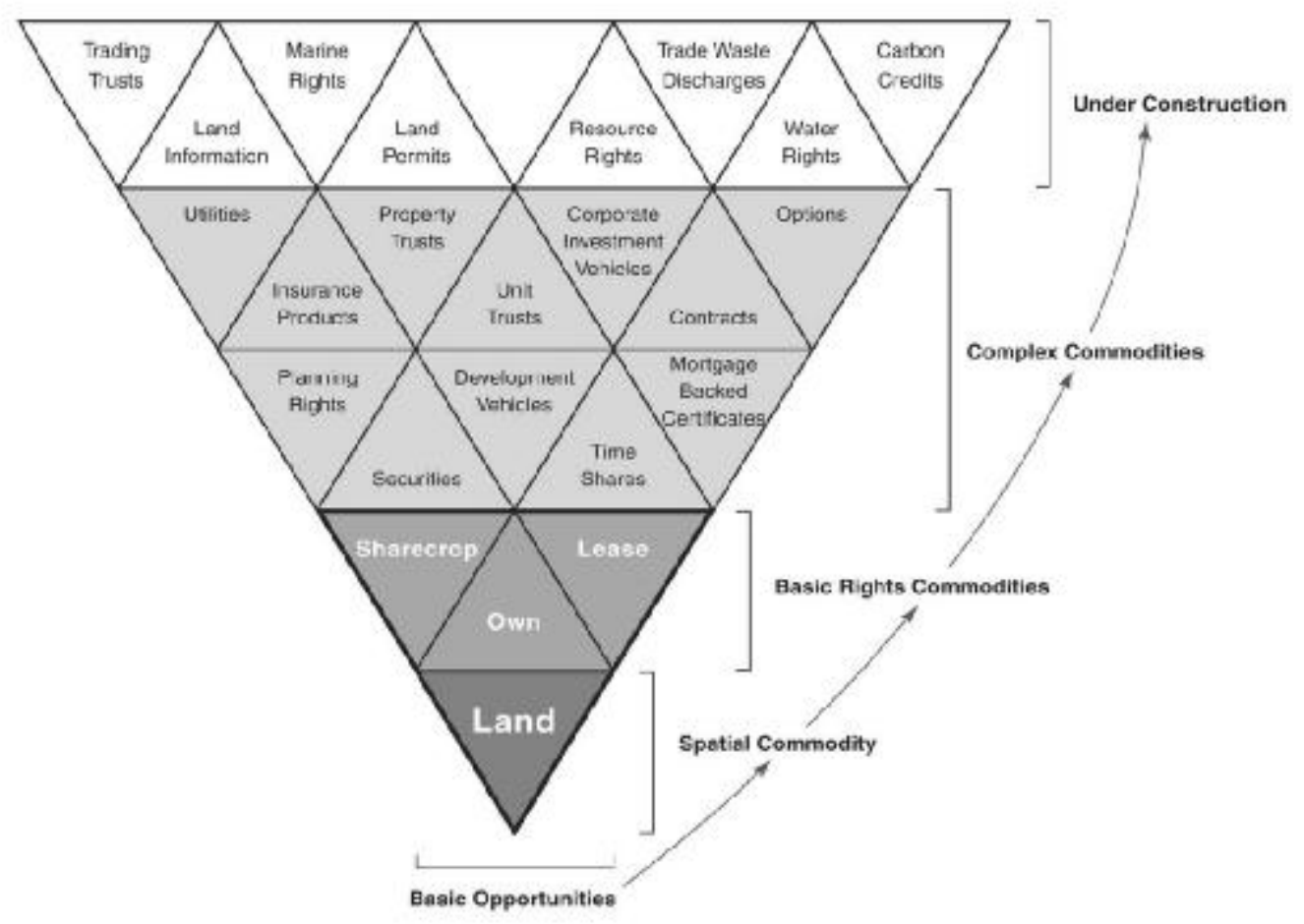

Figure 2. Development of Complex Commodities Wallace and Williamson, $2004 b$

A LAS in the modern context must be adaptable enough to assist these derivative and secondary markets, only some of which are appropriately serviced by the primary layers in the LAS - the digital records of activities of the land registration system and the supporting cadastre. These primary layers are expensive to establish and maintain and their smooth administration is the fundamental building block upon which the frenzy of economic creativity depends. The layers therefore serve many purposes. In the developed European economies, the organisation of cadastres is extensive, absorbing large capital, technological and human resources drawn out of taxation and land market activities. Modern democracies now require widening of the functional base of cadastres to support sustainable development, though puzzlement exists about just how to service the policy goal out of a parcel based system. At this point, the international comparisons are significant. European cadastres are much more multi-purpose than are their Australian cousins. They service the land market, support taxation and valuation systems and, more recently, assist coherent land use management; all essential functions for economically successful democracies.

Of particular interest is the development of much more complex land use arrangements (exemplified by attaching corporate responsibilities for unit and common property management to parcels, and building titles demanding three dimensional management of space), conversion of securities into complex and secondary financial instruments (exemplified by secondary mortgage markets), and creation of leveraged opportunities to participate in ownership and profit taking, while facilitating professional building and

Jude Wallace and Ian Williamson

Developing Cadastres to Service Complex Property Markets

Joint 'FIG Commission 7' and 'COST Action G9' Workshop on Standardisation in the Cadastral Domain Bamberg, Germany, 9 and 10 December 2004 
investment management (through listed property trusts, pension fund investments and other opportunities).

These commodities and activities related to them constitute vast extensions of opportunities for participation in wealth sharing and building through land and ensure economic acceleration. They depend on the smooth, sustained and guaranteed operations of the basic and complex markets in commodities related to land, the public ability to understand (though not necessarily in detail) these diverse activities, and the ability of national systems to attract global investment. An appreciation of the importance of the cadastre as a foundation of these activities is vital: standardisation processes must therefore foresee and even facilitate these trends. Governments need to be especially conscious of how confidence in the LAS and cadastre supports extensive economic activities.

\subsubsection{Secondary mortgage market}

To illustrate from the construction of the secondary mortgage market. The market is the place where primary residential mortgage lenders, mainly banks, sell their mortgages to obtain more funds to originate more loans. It provides liquidity for lenders. To simplify what is a complex legal structure, the market allows banks to bundle up to, say, 500 of their mortgage loans and submit the bundles to an agency which issues mortgage backed certificates. These are offered for sale to investors for a return. The capital received is returned to the lending banks that place it in the primary mortgage market. In the Unified Modeling Language (UML) suggested for the Cadastral Domain Model, the cadastral parcel base (RealEstateObjects) feeds into associations or classes between objects and opportunities (RightsOrRestrictions) identified with natural and legal persons (Subjects). The linkages envisaged are capable of feeding users diverse information about relationships between land/lenders/borrowers and loans or mortgages.

If its organisation and legal capacity permitted, the land registry could offer a facility for bundling loans from high volume lenders at source as an additional service to secondary mortgage markets. In any event, a service consisting of providing the banking and mortgage lenders with data capable of being integrated into their systems might be developed. Ideally the ability to segregate new loans from "churned" loans (loans replacing existing mortgages in response to the hundreds of new financial products on the market) could be of significant significance to economists looking at land markets. If the mortgages were related to geocoded parcels, and systems were available to allow web access to images or photos of the properties plus to land value data, administration savings and a more robust local secondary market would arise. But, whatever happens, attractive and useful packages or services of a kind well beyond current imaginations could be invented by software suppliers once basic UML models are operative.

\subsection{Complex commodities}

In Australia, existing LAS, in particular Torrens registries and their supporting cadastres (Australian land registries generally undertake the legal creation of consolidations, subdivisions and boundary changes of privately owned parcels), are being required to facilitate administration of new commodities (biota, water, carbon futures, forestry rights,

Jude Wallace and Ian Williamson

Developing Cadastres to Service Complex Property Markets

Joint 'FIG Commission 7' and 'COST Action G9' Workshop on Standardisation in the Cadastral Domain Bamberg, Germany, 9 and 10 December 2004 
planning permissions and so on) even where these are separated from land. Characteristics of this "new" property include complex processes of commodification, highly developed administrative and instrumental capacities of governments or private sector agencies, detachment from the parcel based cadastre, and the social and cognitive capacities of participants and organisations.

The continued concentration of land administrators on land and accounting for simple land transactions, particularly changes in ownership, lease and mortgage, fails to account for the frequency with which "new" property is being invented and how more complicated relationships between governments, people and land are developing.

\subsubsection{Water}

The Council of Australian Governments (COAG) (the Prime Minister, state Premiers and Chief Ministers and the President of the Local Government Association) introduced a framework for water reform in 1994. Since then a great deal of attention has been paid to water trading including a plan to use a Torrens style register or approach to provide water titles separated from use of water on land to underpin water trading (ACIL Freehills, 2004). A much more conservative approach was developed by the Government of Victoria and described in a White Paper (2004) on water policy and related reforms. Even these strategic policy reforms demand a great deal of detailed work to support implementation. The White Paper therefore set out an agenda for focusing research on water policy and institutional reform that can illuminate and help ensure that the reforms achieve their intended goals.

The principal water policy reforms set out in the White Paper are described in outline by Professor John Langford, University of Melbourne:

- Separation of water entitlements into three components namely: a share of the water resource; a delivery capacity entitlement; and a licence to use water on a particular area of land.

- Provision for an environmental reserve that catchment management authorities will be accountable for managing (and potentially trading).

- Reduction of current water 'sales' entitlements by $20 \%$ and transfer of that $20 \%$ of low reliability entitlement to the environmental reserve.

- Separation of water right (high reliability entitlement) from 'sales' (low reliability entitlement so that both can be traded independently.

- Allowing $10 \%$ of an irrigation districts bulk entitlement to be disconnected from land. Currently water entitlements can only be held by irrigators who own or lease land (or by urban water authorities and environment).

- Support for reconfiguration of irrigation channels and delivery systems in response to reallocation of water through trading.

- Appropriate governance and regulatory arrangements to ensure accountabilities are clearly defined, conflicts of interest are avoided, and the interests of all entitlement holders and the environment are respected.

There are significant legal, hydrological (especially third party effects), registry, accounting, economic, technical, environmental and social questions to be answered. The core question

Jude Wallace and Ian Williamson

Developing Cadastres to Service Complex Property Markets

Joint 'FIG Commission 7' and 'COST Action G9' Workshop on Standardisation in the Cadastral Domain Bamberg, Germany, 9 and 10 December 2004 
for proponents of water trading of "where is the water?" remains a puzzle in a system which gives titles unsupported by a cadastral or spatial component because the proposal presupposes separation of water from the land on which the resource is used. When water trading is tied to a capacity to use water (traders are both owners and potential users), the system is sufficiently close to existing licensing system; but the intention behind the Australian government design is to have ownership and trading opened up to non-users on the assumption that neo-liberal economics will place the resource with its most efficient user. The proposal to create Torrens titles to water (ACIL Tasman, 2004) seems to depend ultimately on volumetric rather than spatial entitlements in a context of embedded interstate rivalries in resource taking, increasing water shortages and intense contests between agricultural and environmental users. To work commercially, titles to water must never exceed supply. Whether a title system can ensure a connection between water ownership and a supply of water in the right remains problematic.

For cadastral modeling, the class of NonGeoRealEstate could offer itself as an option for a tradeable water right, especially as the concept can embrace a right to fish in a commonly held area (itself depicted as a ServicingParcel) (Lemmen et al, 2003, p 405). However, disconnection of tradeable water from land raises issues of implementation.

\section{THE DYNAMIC WORLD OF PROPERTY MARKETS}

\subsection{Absence of orderly records}

Reappraising Cadastre 2014 in the context of world wide land administration system analysis, Paul van der Molen remarked:

"A serious omission in current land administrating systems is the absence of records of encumbrances and restrictions pursuant to public law. Government measures can restrict the right of disposal by the rightful claimant (the main element in private-property rights) to a certain and on occasion substantial degree. These restrictions can vary from a very mild form (such as the obligation to accept the presence of a lamppost on the land, or a slight financial burden) to a very severe form (such as a mandatory use of the land and, in the most extreme form, expropriation). ... It is important that attention should be devoted to the retention of up-to-date records of this information." (2003, pp 11-12) (Emphasis added.)

The solution of retaining records of this information is unarguable. The question is how to achieve a record base which is affordable, practical and compatible with a robust land market given the even cursory version of the issue in Figure 3.

Jude Wallace and Ian Williamson 


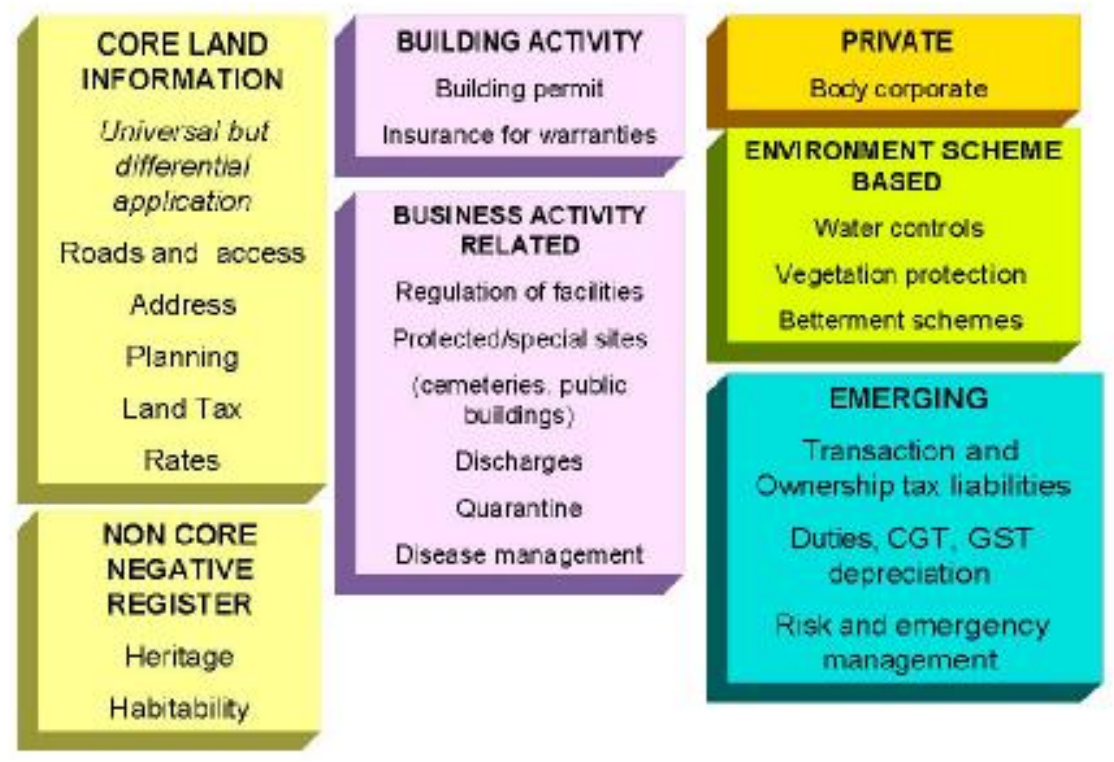

Figure 3. Restrictions and responsibilities affecting land

Publication of restrictions is essential to their effectiveness. It is no longer sufficient for governments to publish restrictions in separated sources pushing systematic disclosure onto people engaging in transactions (usually sale, mortgage and lease of parcels). The existing efforts in Australia to impose some order on the discovery process are directed to creating web based front ends to the multiply enquiry sources. These efforts fail to meet Van der Molen's agenda which demands a much more robust and integrated approach to RRs.

The emerging issue for land administration is then the conversion of parcel generated DCDB into even more useful information. Most users of land information (including agricultural departments, valuation departments and taxation departments) think in terms of properties or even business entitles, not parcels. The modular standard will therefore make use of legal and administrative classes. But even this is proving inadequate.

Technological opportunities offer different solutions for recording and visualizing core restrictions (road access, gas, electricity, cable, sewerage, drainage and water access and charges, zoning, heritage, contamination, and so on). In the standardisation model, opportunities for including significant restrictions in specialization classes of, say, RestrictionArea and NonGeoRealEstate, are available. The model recognises difficulties with public law restrictions where the "holder of the right is abstract (government or even society at large) and where the area of application is not survey defined except in most advanced systems, a typical issue in areas contained in soil polluted areas, flood plains, tidal zones and so on (Lemmen et al, 2003, p 409).

The most promising and alternative means of access of this kind of information envisages developing a shared land information platform, allowing data custodians who manage the particular restrictions to remain independent, but facilitating the access to and overlay of data

Jude Wallace and Ian Williamson

Developing Cadastres to Service Complex Property Markets

Joint 'FIG Commission 7' and 'COST Action G9' Workshop on Standardisation in the Cadastral Domain Bamberg, Germany, 9 and 10 December 2004 
through the more traditional web based systems. The shared land information platform (SLIP) of Western Australia's Department of Land Information is a business activity driven plan to web enable access to and use of significant land information (Western Australian Government, 2004). The core business functions driving the program are emergency management, natural resource management, land development and a register of interests (or, for our purposes, restrictions). This approach recognises significant advances in the spatial information context, including improved GIS systems allowing visual presentation of static data, development of open standards (particularly the Open GIS Consortium, OGC), inter application capacity building and creation of national scale initiatives. In Australia the most important initiative showing exciting opportunities for use in public and private sectors is the geocoded national address file (GNAF).

\subsection{Holistic treatment of land and resources}

Resource taking activities (particularly forestry and mining) form a significant volume of restrictions on land. For practical purposes then, land administration and resource administration should be treated holistically. Resource taking and use of land by surface occupiers are only capable of being mutually successful if their respective public regulators and beneficiaries are able to synthesise their respective activities. Most owners need to know what mining activities fall within the realm of their parcels. Most miners need to know which parcels are directly affected by mining activities. Despite the need for holistic treatment, administration of land and natural resources has traditionally been divided. Indeed typically two kinds of registries have developed and operated so as to make synthesis of information difficult, and in some parts of Australia, even impossible, often because the registers service different functions (Wallace and Williamson, 2004a).

Traditionally, a land register has two components: text defining the interests and diagrams or, in advanced systems, cadastres, defining spatial identity. Together the text and map or, in developed systems, the cadastre, facilitate answering of the five questions of who, what, where, when and why (policy information) about opportunities related to particular land. Modern land cadastres supporting registration are highly sophisticated, and expensive to design, build and manage. Looked at as a whole, they display three-dimensional boundaries: height, width, depth, plus (when we add the text) a fourth dimension of time (how long the interest lasts for).

Design of resource registers tends to be much more prosaic. The types of registers vary greatly; each was developed on an ad hoc basis in response to immediate needs and perceived future needs related to a particular resource. The systems typically develop where resources are valuable, rivalrous in supply and require state enforced allocation of opportunities to extract resources according to regulated standards. The principle administrative task at the forefront of registry activities is regulation of work related to resource extraction. A secondary driver is the need to create marketable rights or titles to the resource in addition to systematizing physical access to yields.

While the registers are specific and independent, information generated to assist management of harvesting activities ideally should be capable of being translated across information generated by land registration activities through a system permitting incorporation of restrictions and responsibilities irrespective of their sources.

Jude Wallace and Ian Williamson

Developing Cadastres to Service Complex Property Markets

Joint 'FIG Commission 7' and 'COST Action G9' Workshop on Standardisation in the Cadastral Domain Bamberg, Germany, 9 and 10 December 2004 


\subsection{Activity regulation and standards}

Use of the land registration system to manage more bureaucratic controls, permits, licences and regulations is widely used in Australia with substantial negative and unforeseen consequences. In 1999, we foreshadowed co-option of the land registration system as part of the regulatory framework of government and warned that this was inappropriate. Land registration is now used, or is capable of being used, to provide building and planning officialdom with opportunities for enforcement of "controls" over standards relating to chemical hazards; wiring and electricity installations; cable capacity; business compliance; domestic safety standards; plumbing, heating, building permits and certificates; registration of plumbers, builders and electricians and other bureaucratic edifices (Wallace, 1999). This option of loading public regulation management into a Torrens type register appears especially attractive to those who require certificates or installations in premises to be evidenced at the time of sale as a means of enforcement of regulations which would otherwise more likely than not be avoided.

Given the improved capacity of cadastres developed in the intervening five years, the point at which a cadastral model should assist this process of cluttering the register and the cadastre to assist day-to-day enforcement of restrictions and regulations affecting land is a real issue. Governments are making more regulations, not less. Some of the more open-ended or multifaceted restrictions and responsibilities (RRs) are problematic in the context of cadastral modelling. A key question is then how or why new RRRs might be incorporated into a cadastral fabric when they are remote from physical objects or even spatial identification. One possible approach suggests answers are available from increased technical precision and/or administrative competencies. These problems associated with emerging RRs are emphasized particularly by management of the marine environment where the marine cadastre is only just developing. In the marine context especially there is a clash between cadastral certainty and rigidity (seen in its focus on defined parcels, or on realisable spatial definitions) and management needs, technical capacities and fuzzy, natural and other kinds of boundaries (Wallace and Williamson, 2004a).

Analysis of land administration trends in Australia in 2004 revealed a naïve anticipation in policy makers and planners in the capacity of an LAS, and consequently a cadastre, to service a range of demands well beyond the standard ones. These include opportunities to deliver much more tax equity in the context of development of sophisticated tax liabilities in the realm of capital gains tax and goods and services taxes. Responsibilities of land owners include modifying their activities according to standards that are relatively indefinite. Noise abatement, view retention, maintenance of mountain ridge lines and similar "standards" appear in regulations seeking to balance private opportunities and responsibilities with the public good. In Australia, the issues are squarely on the political table. Efforts to address major national problems of salinity, land clearing, soil quality and water generated complaints about the sheer quantity and quality of government regulation. These complaints were immediately addressed by a national concern about land regulation which sees organisation of these responsibilities through LAS as one of the solutions.

Report No 7 on Impact of State Government actions on use and enjoyment of freehold and leasehold land in Western Australia of the standing committee on Public Administration and Finance of the Legislative Council of Western Australia suggested thorough reorganization of

Jude Wallace and Ian Williamson $11 / 11$

Developing Cadastres to Service Complex Property Markets

Joint 'FIG Commission 7' and 'COST Action G9' Workshop on Standardisation in the Cadastral Domain Bamberg, Germany, 9 and 10 December 2004 
the relationship between citizens as land owners and their government through parcel based identification of government decisions, even in relation to "plans, policies and strategies":

\section{"Recommendations 35 and 36:}

In the short term, the Department of Land Information (DLI) continue to implement its aim of establishing itself as a 'one stop shop' database of all interests affecting land as an urgent priority.

For the long term, the DLI introduce as soon as practical, an electronic 3d CT which records all interests affecting the land on the CT."

The most far reaching recommendation was:

\section{"Recommendation 37}

That the Government introduce after a 2 year phase in legislation -

(a) Any policy, strategy, plan or other document impacting on administrative decision-making with respect to land use that affects one or more specific certificates of title, is to be of no effect unless registered with Department of Land Information and (b) all policies, strategies, plans or other documents impacting on administrative decision-making with respect to land use that are specific to a certificate of title are to be on registration with the Department of Land Information, cross-referenced with the relevant certificate of title." (page 530) (Emphasis added.)

The genuine and unarguable public concerns that generated this sort of government information chasing exercise are obvious from the consultative processes informing the WA report. However, the recommendations are remarkable for their naïve desire to use certificates of title, rather than generic databases, robust spatial information systems and web enabled access to information as the supply chain. A deeper concern lies with the overall suggestion that it is the business of government to reveal everything about land. The sheer effort involved in determining what pieces of land, rather than what citizens, are affected by policies, strategies, plans and other documents as defined, is enormous. It is not feasible to include all RRs within the realm of orderly administration. The questions are what should be included and how. Thus, on reflection, it is the disorganisation of RRs, not lack of information, that is the real problem.

\section{CONCLUSIONS}

The emerging demands on land administration and cadastral design suggest two central needs:

A definition of the cadastres supported by reasons for its validity, and A path for development of LAS using the cadastre as a vital component of a spatial enabled system.

While a cadastre must be reliable and parcel based, it needs to adapt. Our engineering and design of cadastres needs to take account of trends in markets and especially servicing of development of and trading in complex commodities.

Jude Wallace and Ian Williamson

Developing Cadastres to Service Complex Property Markets

Joint 'FIG Commission 7' and 'COST Action G9' Workshop on Standardisation in the Cadastral Domain

Bamberg, Germany, 9 and 10 December 2004 
Re-engineering is being undertaken at a time when technology supporting the DCDB, parcels and spatial information technology is looking seamless to the web enabled searcher. This capacity is suggesting to policy makers that cadastres can be used for more and more activities. One of the implications for Australia is that the Torrens system is likely to be a victim of its success, and that political demands for it to be used to service activities and administer new commodities fly in the face of much better opportunities offered by GIS, open systems and web enabled management.

At the same time, opportunities for assisting trading in new commodities by building on existing and standard Torrens/cadastral functions, improving their taxation utility, and incorporating trading results into the broader knowledge base for land management and land policy purposes await development. If governments decide trading in new commodities needs no infrastructure support, so be it. So too, if they see the land registry and the related cadastre as the only available vehicles for managing emerging commodities. But at least the decision should be taken rationally rather than as a default arising from failure to examine opportunities and extend the capacity of our cadastres. Neglect should not be the default position.

Our research indicates that change in LAS design is inhibited by limitations of their hardware and software systems, their statutory obligations and restrictions, their inability to retrieve and retain value or funds out of their activities and many other barriers. Though many administrators are excited about the possibilities of new technology and carry a broad interest in improving cadastral services, their ability to convince their political masters of the need to change depends on a convincing case for reconstruction in the context of new ideas and new technology. It is particularly difficult for administrators of any local system to plead for a national or an international vision. In our reality, administrators who see the value of an Open GIS Consortium (OGC) Property and Land Information (PLI) initiative (Lemmen et al, 2003, $\mathrm{p} 401$ ), find convincing political masters of the need to change remains a hurdle. If we are able to utilise an argument about the movements in land markets and consequential need to move land administration forward, our ability to implement a flexible LAS future is improved. A partnership between land administration designers and the powerful interests behind complex commodities in cadastral reform and modular standards would help governments see the possibilities of building on the remarkable efforts to frame modular and adaptable cadastral standards.

Meanwhile, the emerging Web and Internet opportunities are overtaking the cadastre as the focal point in the delivery of land information to both public and professional users. The need to relate spatial and people data to create knowledge and assist decision makers is driving change. The transportation industry example is illustrative.

"GIS are moving beyond traditional data models. The distinction between raster and vector will no longer be meaningful from the user's perspective: GIS will include automated intelligent conversion between these formats as necessary. The collection and storage of georeferenced multimedia, including text, sound, and imagery, are also possible. Georeferenced multimedia can help elected officials, key stakeholders, and the general public understand complex transportation issues, such as proposed changes in transportation infrastructure and services. This can foster a supportive environment for collaborative decision making." (Transportation Research Board, 2004, p 16)

Jude Wallace and Ian Williamson $13 / 13$

Developing Cadastres to Service Complex Property Markets

Joint 'FIG Commission 7' and 'COST Action G9' Workshop on Standardisation in the Cadastral Domain Bamberg, Germany, 9 and 10 December 2004 
This futuristic and enthusiastic account of new technological opportunities in transportation management, including Location-Aware Technologies (LATs) and treatment of time as an object, not an attribute, needs distillation in the context of the emerging demands being made on our cadastres.

\section{REFERENCES}

ACIL Tasman and Freehills, An Effective System of Defining Water Property Titles, Research Report, Land \& Water Australia, 2004, Australian Department of Agriculture, Fisheries and Forestry.

FIG, 1995, Statement on the Cadastre, http://www.fig7.org.uk/publications/cadastre/statement on cadastre.html

Enemark, Stig, Ian Williamson and Jude Wallace, 2004, Building Land Administration Systems, submitted for publication in Journal of Spatial Science .

ICSM, 1999, 'National Cadastral Data Model', version 1.1, Intergovernmental Committee on Surveying \& Mapping (ICSM), Cadastral Data Working Group, June 1999.

ICSM, 2002, 'Harmonised Data Manual: The Harmonised Data Model', Intergovernmental Committee on Surveying \& Mapping (ICSM), 2002.

Kaufmann, Jurg and Daniel Steudler, 1998, Cadastre 2014: A Vision for a Future Cadastral System.

Lemmen, CHJ, P van der Molen, PJM van Oosterom, H Ploeger, CW Quak, JE Stoter and J Zevenbergen (2003), a modular standard for the cadastral domain. In Proceedings of Digital Earth, Bmo, Czec Republic, September 2003

Ploeger, Hendrik D and Jantien E Stoter, Cadastral Registration of Cross-Boundary Infrastructure Objects, FIG Working Week 2004, Athens, http://www.gdmc.nl/publications/\#Conference\%20proceedings\%202004 [accessed 31 October 2004].

Transportation Research Board of National Academies, 2004, Geospatial Information Infrastructure for Transportation: Towards a Foundation for Improved Decision Making, Conference Proceedings 31, Washington, DC, http://trb.org/publications/conf/CP31spatialinfo.pdf [Accessed 1 November 2004].

Van der Molen, Paul, 2003, The Future Cadastres, Cadastres after 2014, FIG Working Week 2003, Paris France, 13-17April, 42 pp.

http://www.eurocadastre.org/pdf/vandermolen2.pdf [Accessed 11 August 2004].

Victorian Government, 2004, White Paper, Our Water Our Future, Department of Sustainability and Environment, Melbourne, www.dse.vic.gov.au

Wallace, Jude, 1999, A methodology to review Torrens systems and their relevance to changing societies from a legal perspective, in Proceedings of the UN-FIG Conference on

Jude Wallace and Ian Williamson
Developing Cadastres to Service Complex Property Markets

Joint 'FIG Commission 7' and 'COST Action G9' Workshop on Standardisation in the Cadastral Domain Bamberg, Germany, 9 and 10 December 2004 
Land Tenure and Cadastral Infrastructures for Sustainable Development, Melbourne, p 299-

316.

Wallace and Williamson, 2004a, Registration of Marine Interests, (submitted to Marine

Policy)

Wallace and Williamson, 2004b, Building Land Markets, Journal of Land Use Policy

publication pending.

Western Australia, 2004, Shared Land Information Platform

http://www.egov.dpc.wa.gov.au/index.cfm?fuseaction=work program.collaborative

\section{ACKNOWLEDGEMENTS}

This work builds on research on modernization of cadastres in the Centre for Spatial Data Infrastructures and Land Administration at The University of Melbourne, particularly a project entitled Incorporating sustainable development objectives into Information and Communications Technology enabled Land Administration Systems. The project requires synthesis of initiatives in Australian web assisted LAS with the historically mature and integrated cadastres of Western Europe. The aim is to define a national Australian vision for a modern LAS capable of servicing the complex property market and delivering sustainable development. The project is supported by the International Science Linkages programme established under the Australian Government's innovation statement Backing Australia's Ability. It is also supported by the Governments of Victoria, Western Australia and New South Wales.

Any errors and infelicities are the sole responsibility of the authors.

\section{BIOGRAPHICAL NOTES}

Jude Wallace is a land policy lawyer working in legal theory and property law. She researches land tenures, land administration systems, land markets and their supporting infrastructures. Her previous experience includes work in national commercial law, computer support for legal practice, and land policy. Her principal appointments include Law Reform Commissioner for Victoria and regulator of the real estate industry.

Ian Williamson's teaching, research and extensive publications cover cadastral, land and geographic information systems, land administration and spatial data infrastructures, in developed and developing countries. He has undertaken research world-wide including for AusAID, the United Nations and the World Bank. He is a Member of the Order of Australia (AM), a Fellow of the Academy of Technological Sciences and Engineering Australia (FTSE), a Fellow of the Institution of Surveyors Australia Inc., a Fellow of the Institution of Engineers Australia, an Honorary Fellow of The Mapping Sciences Institute and the Spatial Sciences Institute Australia, and an Honorary Member of the International Federation of Surveyors (FIG). He was Chairperson of FIG Commission 7 (Cadastre and Land Management) 1994-98 and Director United Nations Liaison for the FIG from 1998-2002. He is a member of the Executive of the United Nations sponsored Permanent Committee for GIS Infrastructures for Asia and the Pacific (PCGIAP) and Chair of its Working Group 3 (Cadastre). He is Head of the Department of Geomatics and Director of the Centre for Spatial Data Infrastructures and Land Administration. He was awarded the Centenary Medal by the

Jude Wallace and Ian Williamson

$15 / 15$

Developing Cadastres to Service Complex Property Markets

Joint 'FIG Commission 7' and 'COST Action G9' Workshop on Standardisation in the Cadastral Domain

Bamberg, Germany, 9 and 10 December 2004 
Prime Minister for service to Australian society in research and geomatics engineering and surveying 2003.

\section{CONTACTS}

Ms Jude Wallace

Senior Research Fellow

Centre for Spatial Data Infrastructures and Land Administration

The University of Melbourne

Victoria 3010

Australia

Phone +61-3-8344-3427

Fax +61-3-9347-2916

Email j.wallace@unimelb.edu.au

Professor Ian P. Williamson AM, FTSE

Professor of Surveying and Land Information

Head, Department of Geomatics

Director, Centre for Spatial Data Infrastructures and Land Administration

The University of Melbourne

Victoria 3010

Australia

Phone

$+61-3-8344-4431$

Fax +61-3-9347-4128

Email $\quad$ ianpw@unimelb.edu.au

URL http://www.geom.unimelb.edu.au/people/ipw.html 


\section{University Library}

\section{- M M I N E R VA A gateway to Melbourne's research publications}

Minerva Access is the Institutional Repository of The University of Melbourne

Author/s:

Wallace, J.;Williamson, I. P.

Title:

Developing cadastres to service complex property markets

Date:

2004

Citation:

Wallace, J. and Williamson, I. P. (2004) Developing cadastres to service complex property markets, in Proceedings, Joint FIG Commission 7 and COST Action G9 Workshop on Standardisation in the Cadastral Domain, Bamberg, Germany.

Publication Status:

Published

Persistent Link:

http://hdl.handle.net/11343/33855 